\title{
Input-output Analysis of Irish Construction Sector Greenhouse Gas Emissions
}

Adolf Acquaye

Technological University Dublin, adolf.acquaye@tudublin.ie

Aidan Duffy

Technological University Dublin, aidan.duffy@tudublin.ie

Follow this and additional works at: https://arrow.tudublin.ie/engschcivart

Part of the Construction Engineering and Management Commons, Environmental Engineering Commons, Environmental Indicators and Impact Assessment Commons, Environmental Monitoring Commons, Natural Resource Economics Commons, Natural Resources and Conservation Commons, Natural Resources Management and Policy Commons, Oil, Gas, and Energy Commons, Power and Energy Commons, Structural Engineering Commons, and the Sustainability Commons

\section{Recommended Citation}

Acquaye, A., Duffy, A.: (2010) Input-output analysis of Irish construction sector greenhouse gas emissions, Building and Environment, Volume 45, Issue 3, Pages 784-791, ISSN 0360-1323, doi:10.1016/ j.buildenv.2009.08.022

This Article is brought to you for free and open access by the School of Civil and Structural Engineering at ARROW@TU Dublin. It has been accepted for inclusion in Articles by an authorized administrator of ARROW@TU

Dublin. For more information, please contact

arrow.admin@tudublin.ie, aisling.coyne@tudublin.ie, gerard.connolly@tudublin.ie.

Funder: Higher Education Authority TSR Strand 1

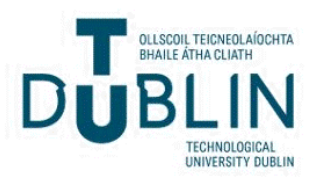




\title{
Input-Output Analysis of Irish Construction Sector Greenhouse Gas Emissions
}

\author{
Adolf A. Acquaye* and Aidan P. Duffy \\ School of Civil \& Building Services Engineering and Dublin Energy Laboratory, Dublin Institute of \\ Technology, Bolton Street, Dublin 1, Ireland. \\ *Corresponding author (adolf.acquaye@dit.ie; Tel: 00353851706231)
}

\begin{abstract}
Ireland is committed to limiting its greenhouse gas (GHG) emissions to $113 \%$ of 1990 levels over the period 2008-12 and to $84 \%$ of 2005 levels by 2020 under the Kyoto Agreement and the EU's '20 20' by 2020 respectively. National policies have targeted many industry sectors but have failed to directly tackle GHG emissions associated with construction activity. This paper estimates energy and GHG emissions intensities of the Irish construction sector and subsectors and estimates its contribution to Irish national emissions. This information is used to identify and assess the impacts of policy measures which would result in a reduction in emissions from the sector in a cost-effective manner. Energy and emissions intensities are estimated using input-output analysis techniques applied to Irish construction sector.
\end{abstract}

In 2005 the Irish construction sector was responsible for the emission of $13.81 \mathrm{mtCO}_{2 \mathrm{eq}}$, comprising $2.37 \mathrm{mt}(17 \%)$ of direct on-site emissions, 5.69mt (41\%) upstream indirect domestic emissions and 5.75mt (42\%) upstream indirect emissions outside the state. Domestically arising direct and indirect emissions accounted for $3.44 \%$ and $8.26 \%$ of national emissions respectively. Approximately three-quarters of construction sector emissions were the result of activities relating to NACE 45.2 'civil and structural construction works, etc'. Given the potential importance of the construction sector to national emissions, there is scope for the implementation of policies which specifically target it. Two such policies are proposed: direct emissions mitigation through a construction EcoDriving initiative; and the provision of information to allow the design and specification of low-emissions materials.

Keywords: Construction; Embodied Energy and Emissions; $\mathrm{CO}_{2 \mathrm{eq}}$ intensity; Sub-Sector Analysis; Energy Policy; Input-Output Analysis; Carbon Accounting

\section{Introduction}

European and Irish national energy policies are based on three key objectives: improving security of supply; assuring international competitiveness; and delivering environmental sustainability. Policy targets focus largely on increasing the share of renewable energy production and implementing energy efficiency measures to reduce environmental emissions and increase the indigenous production of energy. Irish emissions targets are a 
key driver of domestic energy policy. The Kyoto protocol limits national emissions to $13 \%$ above a 1990 baseline and the EU Commission's '20-20 by 2020' policy commits Ireland to reducing emissions by $16 \%$ over 2005 levels by the year 2020. Historically, energy policy has encouraged electrical renewable energy supply (RES-E) through feed in tariffs as well as biofuel production and use through excise exemptions and direct subsidies to producers. The industrial and, in particular, residential sectors have been targeted with grant subsidies for renewables and energy efficient measures. Industrial incentive schemes have been largely targeted at the energy supply, the commercial and manufacturing sectors.

Historically, the construction sector has played an important role in the Irish economy: in 2005 it contributed to $19 \%$ of GDP and $22 \%$ of GNP. According to a report by the United Nations Economic Commission for Europe [1], Ireland had the highest level of construction activity relative to national economic output of all OECD countries between 2004 and 2007. This level of activity is likely to be associated with significant energy use and environmental emissions. Indeed, Sustainable Energy Ireland estimates that the building sector in Ireland consumed 35\% of final energy delivery in 2006 [2]. Suzuki et al [3] and Perez-Lombard et al [4], also states that building energy consumption has steadily increased in recent years and accounts for between $20 \%$ and $40 \%$ of total national consumption in developed countries - however, this considers operational requirements only and ignores construction sector activity. Given the relative size of the Irish construction sector in recent years, it is likely that such emissions have been significant.

Despite the likely importance of construction activity to Irish environmental emissions, Irish government agencies do not directly account for emissions from this sector when collecting and publishing inventories of total national greenhouse gas (GHG) emissions [5]. However, this is not unusual; for example, the European Environment Agency does not gather construction sector data for its European Greenhouse Gas Emission Database [6] although in countries such as the USA [7] construction sector GHG emissions are directly quantified. It is therefore difficult for Irish and European policymakers to design effective initiatives which target and monitor measure emissions from this sector. It is no surprise therefore that there is a recognized lack of research and policy initiatives targeted at Irish construction sector energy use and emissions $[8,9]$.

This study provides information on the energy and emissions intensities of the Irish construction sector by carrying out a systematic analysis of GHG emissions resulting from total energy use in the sector and estimate is its contribution to total emissions in Ireland. This information is used to identify possible policy measures which may result in a reduction in emissions from the sector in a cost-effective manner. Specifically, this paper's objectives are to:

- quantify GHG emissions from the Irish construction sector;

- identify where these emissions arise;

- identify effective mitigation policies; and

- assess the potential impact of these policies on national emissions. 


\section{Methodology}

Construction sector environmental emissions can be characterized as direct or indirect emissions. The former are released as a result of activities directly related to construction on site (for example: excavation, fit-out, plant operation). The latter are associated with the use of energy in construction-related activities necessary for, but preceding site activities these activities are 'upstream' of site work in the construction procurement supply chain (for example: energy used to manufacture building materials, excavation of raw aggregate, design team activities). The methodology uses economic data from Irish construction firms and energy tariffs to estimate direct emissions for different construction site activities in Ireland. Input-output (I-O) analysis is applied to domestic industry sector supply and use data to estimate nationally-arising GHG emissions; these data are amended to include imports and estimate GHG emissions arising outside the state as a result of domestic construction activity. Total emissions therefore include the sum of those arising directly from the construction site, from indirect domestic activities and from indirect international activities.

A detailed explanation of the methodologies used to quantify both direct and indirect construction sector environmental emissions is given below.

\subsection{Sub-Sectoral Direct Emissions Intensities}

Sub-sectoral direct emissions are emissions which arise as a result of energy used directly related to on-site construction and are calculated using primarily energy data collected for each construction sub-sector. Sub-sectoral direct emissions intensities are calculated using 2005 construction company data collected by the Irish Central Statistics Office in their Census of Building and Construction [10]. A summary of the data is presented in Table 1. This contains data from a sample of 728 Irish construction firms and includes expenditure on electricity and fuel by each firm. The sample was chosen to be representative of the Irish construction sector and methodological notes are available from the Irish Central Statistics Office [11]. It is assumed that all fuel used was diesel since the vast majority of plant and construction machinery in Ireland operates on diesel fuel [10, 12]. Energy expenditure is divided among five construction sub-sectors defined by 'The General Industrial Classification of Economic Activities within the European Communities (NACE rev. 1)'. Construction sub-sectors 1-5 are hereafter referred to as 'Ground Works', 'Structural Work', 'Services', 'Finishes' and Plant Operation' respectively. The sub-sectors are defined in detailed below:

Ground Works: $\quad$ Site preparation, demolition of buildings, earth moving, ground work, drilling and boring, etc (NACE 45.1)

Structural Work: Building of complete constructions or part thereof; civil and structural construction works, etc (NACE 45.2)

Services: $\quad$ Building installation, installation of electrical wiring and fittings, insulation, plumbing and other installations, etc (NACE 45.3)

Finishes: $\quad$ Building completion, joinery installation, plastering, floor and wall, 
covering, painting, glazing and general fit-out, etc (NACE 45.4)

Plant Operation: $\quad$ Construction plant and equipments, etc (NACE 45.5)

$<$ Table 1>

The primary energy consumed by the firms in each construction sub-sector was calculated by converting energy expenditure $(€)$ to primary energy (GJ) using the relevant energy tariffs and primary energy factors [13] and [14]. Primary energy factor is primary energy (resource energy) divided by delivered energy where primary energy is that required to supply one unit of delivered energy of the same type taking account of the energy required for extraction, processing, storage, transportation, generation, transformation, transmission, distribution and any other operational requirement for delivery to where the delivered energy will be used [15]. Its use ensures that the actual energy embodied in the natural energy resource is used in the analysis. The sub-sectoral direct energy intensities (GJ/€) were determined for each sub-sector by dividing the sub-sectoral primary energy consumed by relevant turnovers.

Sub-sectoral direct emissions intensities were similarly derived using sub-sectoral primary energy data together with Irish electricity emissions factors derived using the mix of electricity generation fuel types and power plant efficiencies. Diesel emission intensities were calculated using diesel emission factors [16] and added to sub-sectoral direct electricity emissions intensities. The direct emissions intensities for the construction sector were then determined by calculating and summing the Global Warming Potential (GWP) of the most important anthropogenic GHGs with the highest raidiative forcing indices; these are: carbon dioxide $\left(\mathrm{CO}_{2}\right)$; nitrous oxide $\left(\mathrm{N}_{2} \mathrm{O}\right)$; and methane $\left(\mathrm{CH}_{4}\right)$ [17]. Non-energy related GHGs such as halocarbons and indirect GHGs such as tropospheric ozone were ignored. GWP is expressed as carbon dioxide equivalent (referred to here as $\mathrm{CO}_{2 \text { eqs- }}$ - see Sections 2.3 below).

The sub-sectoral direct emissions intensity for any construction sub-sector can be represented by:

$$
\mathrm{i}_{\mathrm{dj}}=\left[\frac{Q_{(e, d) j} \times T_{(e, d)} \times P_{(e, d)}}{E_{j}}\right] \times \sum_{k=1}^{3} F_{(e, d) k}
$$

Where: 
$\mathrm{i}_{\mathrm{dj}}=$ Sub - sectoral direct emissions intensities

$\mathrm{Q}=$ Quantity of electricity and diesel consumed [Euro]

$\mathrm{T}=$ Average energy tariff [GJ/Euro]

$\mathrm{P}=$ Primary Energy Factor

$\mathrm{E}=$ Output of each subsector [Euro]

$\mathrm{F}=$ Emissions Factor for the three GHGs $[\mathrm{t} / \mathrm{GJ}]$

$\mathrm{j}=$ Construction sub - sector $\mathrm{j}$

$\mathrm{e}=$ electricity

$\mathrm{d}=$ diesel

The overall sub-sectoral direct emissions intensity $\left(i_{d t}\right)$ is then calculated as an average of the sub-sectoral direct emissions intensities $\left(i_{d j}\right)$ which is weighted according to the output of each sub-sector. This is represented as:

Equation 2:

$$
\mathrm{i}_{\mathrm{dt}}=\frac{\sum_{j=1}^{5} \mathrm{i}_{\mathrm{dj}} \times E_{j}}{\sum_{j=1}^{5} E_{j}}
$$

\subsection{Indirect Input-Output Emissions Intensities}

Indirect input-output emissions are emissions arising from energy use not directly related to on-site construction but upstream of on-site construction and are calculated using primarily input-output data. Indirect input-output emissions intensities were estimated using data from the Irish national I-O tables [18] which are compiled using data from national accounts as well as other national economic sources to show economic transactions between all product sectors of the national economy. The input coefficients of the economy wide I-O tables are used to derive indirect input-output emissions intensities in the construction sector. This methodology is widely used and described in literature (see inter alia Bullard et al [19], Lenzen et al [20] and Stromman et al [21]). In summary, the approach involves using Irish I-O tables [18], average energy tariffs [13] and primary energy factors [14] to determine total I-O and direct I-O energy intensities per unit monetary value of construction sector output. Indirect I-O energy intensity is calculated as the difference between the total I-O and direct I-O energy intensities. The indirect I-O energy intensity is then converted to indirect I-O emissions intensity using the emissions factors presented in Table 2. The direct requirement coefficient matrix of the Irish I-O tables was used to evaluate the direct I-O energy intensity and the Leontief inverse matrix used to calculate the total domestic energy intensity [22, 23]. This methodology estimates domestic I-O indirect energy and emissions intensities since the Irish I-O tables do not 
account for imported goods and services.

I-O analysis suffers from a number of well-recognised limitations [24]. For example, the Proportionality Assumption presumes that the inputs to each sector are proportional to their outputs so that if the output of a sector increases, then the consumption of intermediaries and primary inputs to that sector will also increase proportionally. Hence, it is assumed that energy consumption is directly proportionate to output, although economies of scale should act to reduce marginal energy consumption. The Homogeneity Assumption proposes that each sector produces a uniform output using identical inputs and processes; however, this is obviously not the case since each sector containing many different products and services. I-O analysis assumes the uniform conversion of economic data into physical quantities (energy and emissions in this case) within a sector. For example, national average energy tariffs are used to convert economic data to energy consumed, although such tariffs will vary across different industries. Finally, the data used for I-O analysis can artificially bound the supply network and exclude important business processes or even geographic locations.

This paper attempts to address some of these limitations. In addition to the current methodology used to calculate domestic indirect input-output emissions intensity described above, this paper expands the boundary to include upstream energy inputs for imported goods and services. EuroStat [25] states that if I-O tables are used to calculate the total energy intensity of a product then the energy used to produce imported inputs should also be included in order to account for whole life energy inputs. The addition of energy inputs into imported construction sector goods and services is important in an open economy such as Ireland's [26] [27] and provides greater information for decision making by designers and policy makers by considering total global impacts. Furthermore, given that approximately $56 \%$ of Irish imports are from the EU [28] an understanding of the sources of emissions are important from an EU policy perspective. A further development of the methodology increases accuracy through the disaggregation of the energy supply sectors using disaggregation coefficients thus mitigating errors associated with the assumptions of homogeneity and uniform conversion. These aspects of the methodology are described in greater detail below.

\subsubsection{Energy Inputs of Imported Goods and Services}

The main advantage of input-output analysis in energy and environmental research studies relates to the extended system boundary that the analysis offers over process-based approaches [29] [30] which are limited to the product flows under consideration where the energy used in the supply chain up to and including the production of a product is measured and an energy intensity calculated. However, because all the infinite energy inputs into a product cannot be measured in this way, a system boundary has to be set thus truncating some of the energy inputs. I-O analysis overcomes this limitation through the use of the Leontief Inverse Matrix. The Leontief Inverse Matrix employs a power series approximation to account for all upstream economic inputs to a product sector; consequently, all energy expenditure is also accounted for. However, because the Irish I-O 
tables measure domestic flows only, the energy inputs into imported products have been omitted. In order to extend the I-O system boundary to include imported goods and services the methodology set out in the Eurostat European System of Accounts I-O Manual [25] is applied to rederive the Irish direct requirement and Leontief inverse matrices.

\subsubsection{Disaggregation of Energy Supply Sectors}

A limitation of I-O analysis is the aggregation of many different products into one sector in the national I-O tables [31] thus reducing its applicability to a specific product or product sector. For example, in the Irish I-O tables, some energy supply sectors are aggregated together either with non-energy supply sectors or other energy supply sectors (for example, the 'Petroleum and Other Manufacturing' sector is an aggregation of an energy supply sector, 'Petroleum' and non-energy supply sector 'Other Manufacturing.). Therefore, to address the aggregation problem a disaggregation constant, is introduced to separate the energy supply sectors into individual energy sources to which emissions factors can be applied. A detailed analysis of the disaggregation of the energy supply sectors in Ireland has been undertaken by Wissema [32].

The Irish I-O table consists of three aggregated energy supply sectors, namely:

1 Mining and Quarrying Products (an aggregation of peat, crude oil and coal);

2 Petroleum and Other Manufacturing Products (an aggregation of petroleum and other non energy products); and

3 Electricity and Gas (an aggregation of electricity, natural gas and renewable energy).

The use of the disaggregation constants has a two-fold advantage. Firstly, non-energy supply sectors are eliminated from the analysis. Secondly, it enables individual primary energy factors and energy tariffs to be used instead of average values for two or more aggregated energy supply sectors (for example, electricity and gas).

The methodology undertaken in the evaluation of the indirect import emissions intensity of the construction sector is described below.

1 The direct requirement matrix and the Leontief inverse matrix were re-derived to include imported goods and services according to the methodology outlined by the European System of Accounts [25].

2 The direct I-O and total I-O energy intensities (GJ/€) of the construction sector were calculated using energy tariffs [13], primary energy factors [14], direct requirement coefficients and total requirement coefficients respectively [18] as described by Treloar [22].

3 These were disaggregated using the disaggregation constants derived for Ireland by Wissema [32].

4 The indirect I-O energy intensities (domestic plus imported) were calculated as the difference between the total I-O and direct I-O energy intensities of the construction sector.

5 Indirect $\mathrm{I}-\mathrm{O} \mathrm{CO} \mathrm{CO}_{2}, \mathrm{~N}_{2} \mathrm{O}$ and $\mathrm{CH}_{4}$ emissions intensities (domestic plus imported) were calculated from the indirect I-O energy intensity using the emission factors in Table 
Total sub-sectoral emissions intensities were calculated as the sum of the sub-sectoral direct emissions intensities $i_{d j}$ and the indirect I-O emissions intensities for the different global warming gases. A flow chart description of the methodology is presented in Figure 1 below.

$<$ Figure 1>

\section{$2.3 \mathrm{CO}_{2}$ Equivalence $\left(\mathrm{CO}_{2 \mathrm{eq}}\right)$}

Energy-derived GHGs such as $\mathrm{CO}_{2}, \mathrm{~N}_{2} \mathrm{O}$ and $\mathrm{CH}_{4}$ have different impacts on global warming and can be weighted according to their global warming potential (GWP). This is the ratio of the warming caused by a substance to the warming caused by a similar mass of carbon dioxide and is termed $\mathrm{CO}_{2}$-equivalent $\left(\mathrm{CO}_{2 \mathrm{eq}}\right)$. The GWP of the energy-related GHGs regulated under the Kyoto Protocol over a 100 year timeframe which are relevant to this study are: $\mathrm{CO}_{2}-1 ; \mathrm{N}_{2} \mathrm{O}-310$; and $\mathrm{CH}_{4}-21$. The GWPs for each of the above emissions were summed to give total $\mathrm{CO}_{2 \mathrm{eq}}$ intensities for the construction sector.

\section{Results and Analysis}

\subsection{Sub-Sectoral Direct Emissions Intensity}

Figure 2 shows annual sub-sectoral direct emissions intensities $\left(i_{d j}\right)$ for 2006 and also presents the total direct emissions from each construction sub-sector. Table 2 shows the emission factors for electricity and fuel used to calculate the sub-sectoral direct emissions intensities $\left(i_{d j}\right)$.

$<$ Figure 2>

$<$ Table $2>$

From Figure 2 it can be seen that the sub-sectoral direct emissions intensities, $i_{d j}$ are highest for Plant Operation (that is, $i_{d 5}=493.27 \mathrm{t} / € \mathrm{~m}$ ) followed by Ground Works $\left(i_{d 1}=\right.$ $258.87 \mathrm{t} / € \mathrm{~m}$ ) while other sub-sectoral direct intensities were considerably lower and varied between 25 and 70t/€m. The emissions intensities of the Ground Works and Plant Operation sub-sectors are particularly high because of the significant use of construction machinery associated with the activities in these sectors (e.g. use of excavation machinery and haulage) and the associated greater fuel consumption. Although Structural Work had a relatively low sub-sectoral direct emissions intensity it can be seen in Figure 2 that it contributes significantly to the overall sub-sectoral direct emissions intensity $\left(i_{d t}\right)$ because of the relatively high level of activity (and turnover) in that sub-sector. Conversely, Plant Operation - which has highest emissions intensity - did not contribute significantly to 
overall sub-sectoral direct emissions intensity because of the low output of that sub-sector.

The overall sub-sectoral direct emissions intensity $i_{d t}$ for the Irish construction sector was found to be $71.92 \mathrm{tCO}_{2 \mathrm{eq}} / \mathrm{m€}$. It is worth noting that this figure is dominated by $\mathrm{CO}_{2}$ emissions with only a negligible contribution from $\mathrm{N}_{2} \mathrm{O}$ and $\mathrm{CH}_{4}$ which between them contribute less that $1 \%$ of the total $\mathrm{CO}_{2 \mathrm{eq}}$ of direct emissions.

\subsection{Indirect Input-output emissions intensity}

Primary energy factors and average energy tariffs used to derive the indirect I-O energy and emissions intensities are presented in Table 3 while sectoral disaggregation constants are shown in Table 4. The indirect I-O emissions intensities arising from both domestic and international sources are presented in Table 5.

$<$ Table 3>

$<$ Table 4>

$<$ Table 5>

Emissions are dominated by $\mathrm{CO}_{2}(344.99 \mathrm{t} / \mathrm{m€})$ with negligible contributions from both $\mathrm{N}_{2} \mathrm{O}$ $(0.0079 \mathrm{t} / \mathrm{m} €)$ and $\mathrm{CH}_{4}(0.0109 \mathrm{t} / \mathrm{m} €)$. The equivalent indirect input-output $\mathrm{CO}_{2 \mathrm{eq}}$ emissions intensity was therefore estimated to be $347.7 \mathrm{t} / \mathrm{m} €$ of which $173.2 \mathrm{t} / \mathrm{m} €$ was from domestic sources. The contributions of domestically- and internationally-arising indirect emissions to total indirect emissions are illustrated in Figure 3 where it can be seen that almost equal proportions of emissions arise within and without the jurisdiction.

$<$ Figure $3>$

Figure 4 shows the breakdown of total emissions (comprising direct sub-sectoral, indirect domestic and indirect import) for the Irish construction sector. The data indicates that $17.1 \%$ (2.37 million tonnes $\mathrm{CO}_{2 \mathrm{eq}}$ ) of total emissions originate domestically from sources directly related to construction activities. Imports accounted for approximately $41.6 \%(5.75$ million tonnes of $\mathrm{CO}_{2 \mathrm{eq}}$ ) while $41.3 \%$ (5.69 million tonnes of $\mathrm{CO}_{2 \mathrm{eq}}$ ) were emitted nationally.

$<$ Figure 4 $>$

Total sub-sectoral emissions intensities and total emissions by sub-sector are presented in Figures 5 and 6 respectively. The total sub-sectoral emissions intensities of the Irish construction sector is the sum of the sub-sectoral direct emissions intensity and indirect I-O emissions intensities from Figures 2 and 3 respectively. It can be seen in Figure 5 that the emissions intensity of Plant Operation is highest $\left(840.95 \mathrm{tCO}_{2} \mathrm{eq} / \mathrm{m} €\right.$ including imports) followed by Ground Works (606.55) and Sturctural Work (418.96). The emissions intensities for Services and Finishes are similar at 380.30 and 373.29 tCO2eq/m€ respectively (including imports). Figure 6 shows that Structural Work had the highest total 
emissions (10.6 $\mathrm{mtCO}_{2 \mathrm{eq}}$ including imports and $6.19 \mathrm{mtCO}_{2 \mathrm{eq}}$ excluding imports) while the total emissions of the other sub-sectors ranged from 0.26 to $2.10 \mathrm{mtCO}_{2 \text { eq }}$ (including imports) and 0.19 to $1.14 \mathrm{mtCO}_{2 \mathrm{eq}}$ (excluding imports).

The total emissions intensity of the Irish construction sector weighted by sub-sectoral turnover was estimated at $245.1 \mathrm{tCO}_{2 \mathrm{eq}} / \mathrm{m} €$ excluding imports. This figure increases to 419.6 $\mathrm{tCO}_{2 \mathrm{eq}} / \mathrm{m€}$ when energy inputs into imported construction-related goods and services are considered. Therefore, $58.4 \%$ of construction sector emissions are the result of activities within Ireland while $41.6 \%$ of emissions arise internationally.

$<$ Figure 5 $>$

$<$ Figure 6>

\subsection{Discussion}

Given a total estimated turnover in the Irish construction sector of $€ 32.99$ billion in 2005 [33] and the total domestic emissions intensity derived above, total construction sector-related national emissions for that year are estimated to be 8.11 million $\mathrm{tCO}_{2 \mathrm{eq}}$. The Irish Environmental Protection Agency [5] reported that total national emissions in 2005 were 69.2 million tonnes $\mathrm{CO}_{2 \mathrm{eq}}$ when the agricultural, transportation, waste, energy, residential, industrial and commercial sectors were accounted for. The construction sector therefore contributed to approximately $11.7 \%$ of total domestically-arising $\mathrm{CO}_{2 \mathrm{eq}}$ emissions in 2005. Given that direct emissions account for $29.4 \%$ of total domestic construction sector emissions, some $2.38 \mathrm{mtCO}_{2 \mathrm{eq}}$ was emitted directly on Irish construction sites accounting for $3.44 \%$ of national emissions; indirect emissions accounted for $5.73 \mathrm{mt} \mathrm{CO}_{2 \mathrm{eq}}$ or $8.26 \%$ of national emissions. If all products and services required for the Irish construction sector were produced domestically (i.e. including for imported emissions), then construction activity would have accounted for almost $20 \%$ of national emissions.

Ireland's target under the Kyoto Protocol is to limit 2008-2012 $\mathrm{CO}_{2 \mathrm{eq}}$ emissions to $13 \%$ above the 1990 baseline of 55.6 million $\mathrm{tCO}_{2 \mathrm{eq}}$ [5]. However by 2005, emissions were already approximately 13.6 million $\mathrm{tCO}_{2 \mathrm{eq}}$ or $24.5 \%$ greater than the baseline. The Irish Government has responded to limit emissions' growth by introducing a range of policies across many industry sectors. For example, a range of financial incentives (primarily capital subsidies) have been used to promote the uptake of renewable microgeneration in the residential sector while feed in tariffs are targeted at large-scale renewables in the energy sector. Similarly the transport, agricultural and industrial sectors have been targeted through a range of national and EU emissions mitigation policies. The construction sector, however, is not specifically targeted by national policies although many industries which contribute to indirect emissions fall under policies aimed at the manufacturing and services sectors. For example, the cement industry is subject to the European Emissions Trading Scheme (EU ETS) while other construction product production facilities can avail of capital grants and tax incentive schemes for energy efficient plant and equipment. However, no specific policies exist to promote energy efficient behaviour on construction sites. 


\subsection{Direct Emissions Mitigation}

It has been seen above that Structural Work activities account for the majority (almost $76 \%$ ) of direct emissions followed by Ground Works (10\%). Any policies to reduce on-site construction-sector emissions must therefore target these activities. Construction company energy expenditure [10] and average energy tariffs [13] indicate that the majority of direct emissions are the result of fuel consumption in vehicles $(65.3 \%)$ and stationary plant with comparatively low emissions from on-site electricity consumption (10.3\%). Policies should therefore focus on minimising plant energy consumption and, to a lesser extent, on-site electricity use. Regarding the former, construction-site EcoDrive principles could be promoted through information campaigns and driver/plant operator training. Key principles include good vehicle maintenance, minimising unnecessary loads, optimising acceleration and speed, combining trips, avoiding sudden braking and avoidable engine idling. Eco-drive programmes in other industry sectors have been shown to reduce emissions by as much as $25-30 \%$ in the short term and $12-15 \%$ in the long term [34]; had such a programme been in place in 2005 it could have reduced direct construction sector emissions by up to $357 \mathrm{ktCO}_{2 \mathrm{eq}}$ or $0.5 \%$ of national emissions.

\subsection{Specifying Low-Emissions Materials}

A second, complimentary policy option to reduce the energy intensity of the construction sector involves the provision of emissions information by suppliers in the sector. For example, materials' suppliers or contracting firms would be obliged to provide energy and emissions data for their products and services based on common metrics (e.g. $\mathrm{kgCO}_{2} / \mathrm{kg}$ or $\mathrm{gCO}_{2} / €$ turnover). This would allow clients and designers choose materials and organisations with relatively low emissions, thus reducing the overall emissions intensity of the sector. Emissions data would be available on recycled structures and materials as well as new construction products and construction services. Some progress is occurring in this field with a number of databases available (see inter alia Sustainable Energy Research Team [35] and BRE Green Guide to Specification [36]). However, the use of these data is voluntary, they exist for only a limited range of products and are geographically restricted. Moreover, although the data is available for many building components, it is not normally product-specific thus restricting a designer's ability to specify substitute, low-embodied energy products. Such limitations could be overcome by regulation, where governments require the provision of embodied energy information by suppliers and set minimum emissions standards for procuring buildings. Data suggests that the energy intensities of some common building products can vary by a factors of between 2 (concrete) and 7 (steel) [35], suggesting that substantial emissions reductions are achievable through good design and specification. An advantage of this approach is that it would reduce emissions throughout the supply chain in the direct, indirect domestic and indirect import areas. For example, good design practice leading to a reduction of $20 \%$ in indirect emissions (domestic and import) would have cut Irish construction section emissions by $2.29 \mathrm{mtCO}_{2 \mathrm{eq}}$ in 2005; domestic emissions would have been reduced by $1.6 \%\left(1.14 \mathrm{mtCO}_{2 \mathrm{eq}}\right)$. 


\section{Conclusions}

In 2005 the Irish construction sector was responsible for the emission of $13.81 \mathrm{mtCO}_{2 \mathrm{eq}}$, comprising $2.37 \mathrm{mt}(17 \%)$ of direct on-site emissions, $5.39 \mathrm{mt}(41 \%)$ upstream indirect domestic emissions and $5.75 \mathrm{mt}(42 \%)$ upstream indirect emissions outside the state; corresponding emissions intensities were found to be $71.92 \mathrm{tCO}_{2 \mathrm{eq}} / \mathrm{€m}, 173.2 \mathrm{tCO}_{2 \mathrm{eq}} / \mathrm{€m}$ and $174.5 \mathrm{tCO}_{2 \mathrm{eq}} / \mathrm{\epsilon m}$ respectively. Domestically arising direct and indirect emissions accounted for $3.44 \%$ and $8.26 \%$ of national emissions respectively or $11.7 \%$ of national emissions. Approximately three-quarters of construction sector emissions were the result of activities relating to NACE 45.2 'building of complete constructions or part thereof; civil and structural construction works, etc.' Irish construction sector output has contracted from a high of 22\% of GNP in 2007 (expenditure basis) and is projected to fall as low as 12\% in 2009 [37]. This will lead to significant GHG emissions reductions from the sector and has undoubtedly contributed to national reductions from all economic sectors over this period. However, any reductions are likely to be short-lived and when construction activity returns to historic levels (15-20\% of GNP), emissions are again likely to approach the quantities estimated above.

Existing emissions mitigation policies already target many aspects of construction sector supply chains: the cement industry is one such example where the EU ETS disincentivises emissions. However, given the potential importance of the construction sector to national emissions, there is further scope for the implementation of policies which specifically target it. Two such policies are proposed: direct emissions mitigation through a construction EcoDriving initiative; and the provision of information to allow the design and specification of low-emissions materials followed by regulation of construction procurement to achieve maximum construction emissions standards. Such policies could have reduced Irish national emissions by $0.5 \%$ and $1.6 \%$ respectively in 2005 .

\section{Acknowledgement}

The authors will like to thank Dr Patrick Quill of the Central Statistics Office in Dublin for his valuable advice on the Supply and Use and Input-Output Tables for Ireland.

\section{References}

[1] United Nations Economic Commission for Europe. Republic of IrelandNational Market Report 2006. Annual Meeting of Timber Committee 3rd-4th October 2006.

[2] Sustainable Energy Ireland. Energy in Ireland 1990 - 2006 Report. Energy Policy Statistical Support Unit. Cork, Ireland. 2007.

[3] Suzuki M, Oka T, Okada K. The estimation of energy consumption and $\mathrm{CO}_{2}$ emission due to housing construction in Japan. Energy and Buildings 1995; 22 (2) 165-169. 
[4] Pérez-Lombard L, Ortiz J, Pout C. A review on buildings energy consumption information. Energy and Buildings 2008; 40 (3): 394-398.

[5] Environmental Protection Agency. 2006 greenhouse gas emissions in Ireland. Wexford Ireland. 2007.

[6] European Environmental Agency. Annual European Community greenhouse gas inventory 1990-2006 and inventory report 2008; N0. 6. ISSN 1725-2237. EEA Technical Report. 2008

[7] United States Environmental Protection Agency, US EPA. Potential for Reducing Green House Gas Emissions in the construction sector; Sector Strategies. Washington DC,USA.2009[8] Forum for the Construction Industry. Applied construction innovation centre initial feasibility study. 2003.

[9] University College Dublin Energy Research Group. Green Paper: Towards a Sustainable Energy Future for Ireland. Department of Communication, Energy and Natural Resource. 2007.

[10] Central Statistics Office, CSO (2007) 2005 Census of building and construction. ISSN: 1393-7103. Ref: 134/2007. Available at: http://www.cso.ie/releasespublications/documents/construction/current/cenbuild.pdf [11] Central Statistiic Office. Background Notes to Census of Building and Construction Methodology. 2008. Available at:

http://www.cso.ie/surveysandmethodologies/surveys/census_of_building_and_construc_me thodology.htm

[12] Limerick Energy. Renewable diesel-Gen 2. 2008. Available at:

http://www.limerickenergy.com/renewable/index.html

[13] International Energy Agency, IEA, Detailed Energy Balance for Ireland.2000

[14] Sustainable Energy Ireland. 1990-2006 Energy Statistics for Ireland, Energy Policy

Statistical Support Unit. Cork, Ireland. 2007

[15] CEN Technical Committee (2004). Heating Systems in Buildings. European Standards. TC 228 WI 00228027

[16] National Lab for Sustainable Energy (2007) Emissions inventories: Emission factors, Published by Aarhus Universitet. 2007

[17] Intergovernmental Panel on Climate Change (2007) IPCC Fourth Assessment Report (AR4): Climate Change 2007 Synthesis Report, IPCC.

[18] Central Statistics Office. Supply and Use and Input-Output Tables; Published by the Stationary office, Dublin, Ireland; ISSN 1649-5918, ISBN 0-7557-7134-606. 2006

[19] Bullard CW, Penner P.S. and Pilati DA. Net Energy Analysis: Handbook for Combining Process and Input-Output Analysis. Resources and Energy 1978; 1: 267-313. [20] Lenzen M, Dey, C. Truncation error in embodied energy analyses of basic iron and steel products. Energy 2000; 25: 577-585.

[21] Strømman AH, Solli C. Applying Leontief's Price Model to Estimate Missing Elements in Hybrid Life Cycle Inventories. Journal of Industrial Ecology 2008; 12 (1): 26-33.

[22] Treloar, G. J. Extracting embodied energy paths from input-output based hybrid energy analysis method. Economic Systems Research 1997; 9: 375-391.

[23] Miller, R. E. and P. D. Blair. Input-output analysis: Foundations and extensions. Englewood Cliffs, NJ: Prentice-Hall. 1985 
[24] Hendrickson, C, Horvath, A and Joshi, S. Economic Input-Output Models for Environmental Life-Cycle Assessment. Env. Sci. \& Tech. Policy Analysis 1998; 32(7): 184-191.

[25] EuroStat. The ESA 95 Input-Output Manual - Compilation and Analysis -. European Commission. Version 2002.

[26] Swedish Chamber of Commerce Ireland. Spotlight Sweden. SCCI News 2006; 7: 1-10. [27] Davy. Davy on the Irish economy: Construction risk manageable. 2005.

[28] Central Statistics Office (2004) Ireland and the EU, 1973-2003: Economic and Social Change. Published by the Stationary office, Dublin, Ireland

[29] Born P, Janiskee RL. Input-output analysis: input of energy, CO2, and work to produce goods. Journal of Policy Modelling 1996. 18:217-221.

[30] Hayami H, Nakamura M, Suga M, Yoshioka K. Environmental Management in Japan: Applications of Input-Output Analysis to the Emission of Global Warming Gases. [31] Mongelli I, Suh S, Huppes G. A Structure Comparison of two Approaches to LCA Inventory Data, Based on the MIET and ETH Databases. Int J LCA 2005; 10(5): 317-324. [32] Wissema W. Building Social Accounting Matrix for Ireland with specific details in relation to energy and carbon dioxide emissions; Institute for International Integration Studies 2006; Dublin- Ireland; 170: 1-28.

[33] Central Statistics Office (2008) Construction and Housing in Ireland; 2008 Edition. Published by the Stationary office, Dublin, Ireland. ISBN: 1-4064 2074-6

[34] Department of Transport (2008). Vision 2020-Sustainable Travel and Transport: Public Consultation Document. Transport House, Dublin, Ireland [35] Sustainable Energy Research Team (2008) Inventory of Carbon and Energy v1.6a. University of Bath, UK

[36] Building Research Establishment. BRE Green Guide to Specification, ISBN 978-1-84806-071-5. $4^{\text {th }}$ Edition. 2009

[37] DKM (2009) Construction Industry Indicators - Issue 16. Prepared for the Department of the Environment, Heritage and Local Government. DKM Economic Consultants Limited, Dublin. Accessed online $25^{\text {th }}$ August 2009: http://www.dkm.ie/uploads/pdf/reports/Construction\%20Indicators\%20FINAL\%20Issue\% 20Mar\%202009.pdf 


\section{List of Figures}

Figure 1: Flow diagram showing methodology for calculating total construction sector emissions intensities. I/O tables for both domestic and imported products are used to estimate domestically and internationally-arising emissions

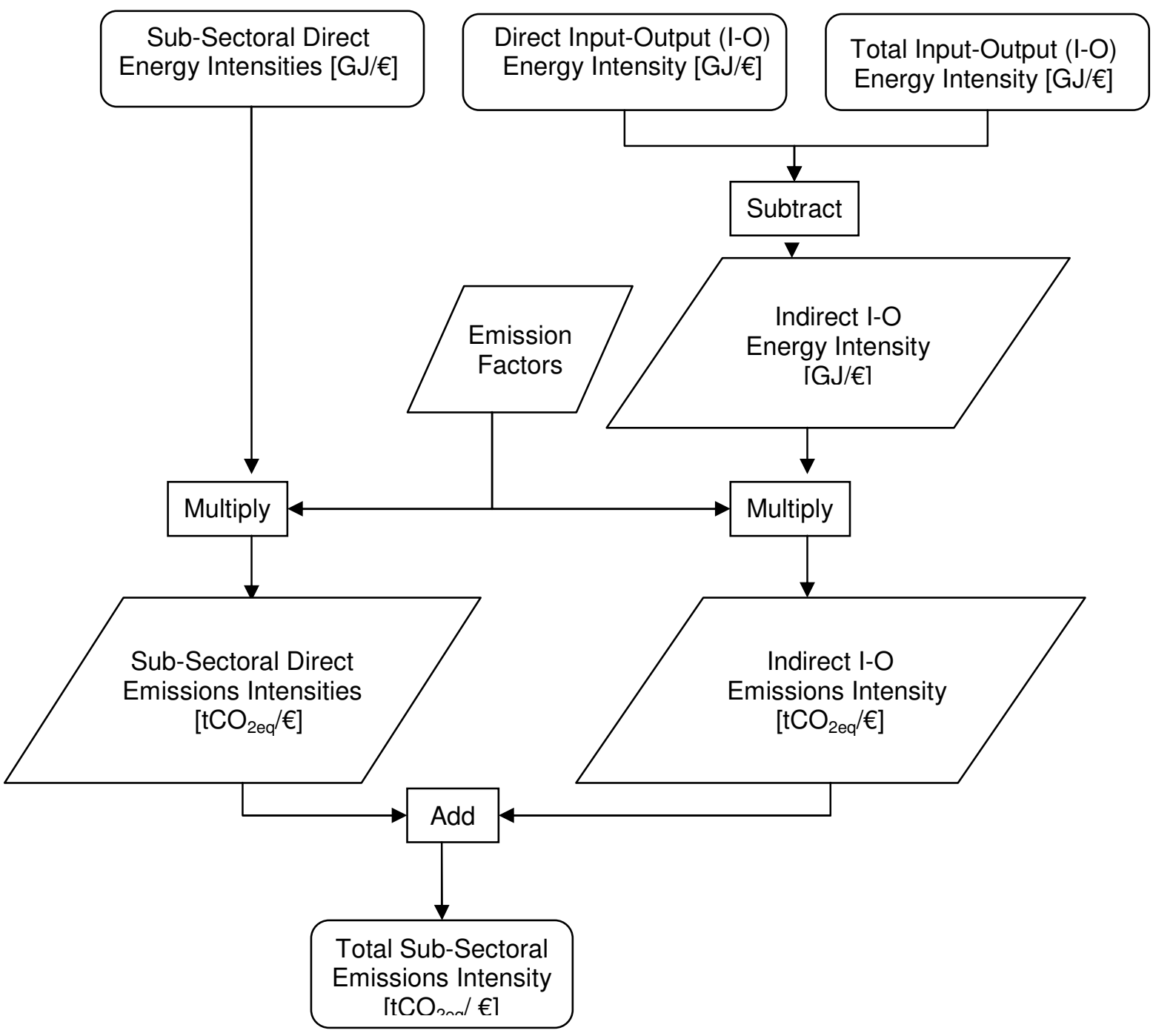


Figure 2: Sub-Sectoral Direct Emissions and Sub-Sectoral Direct Emissions Intensities

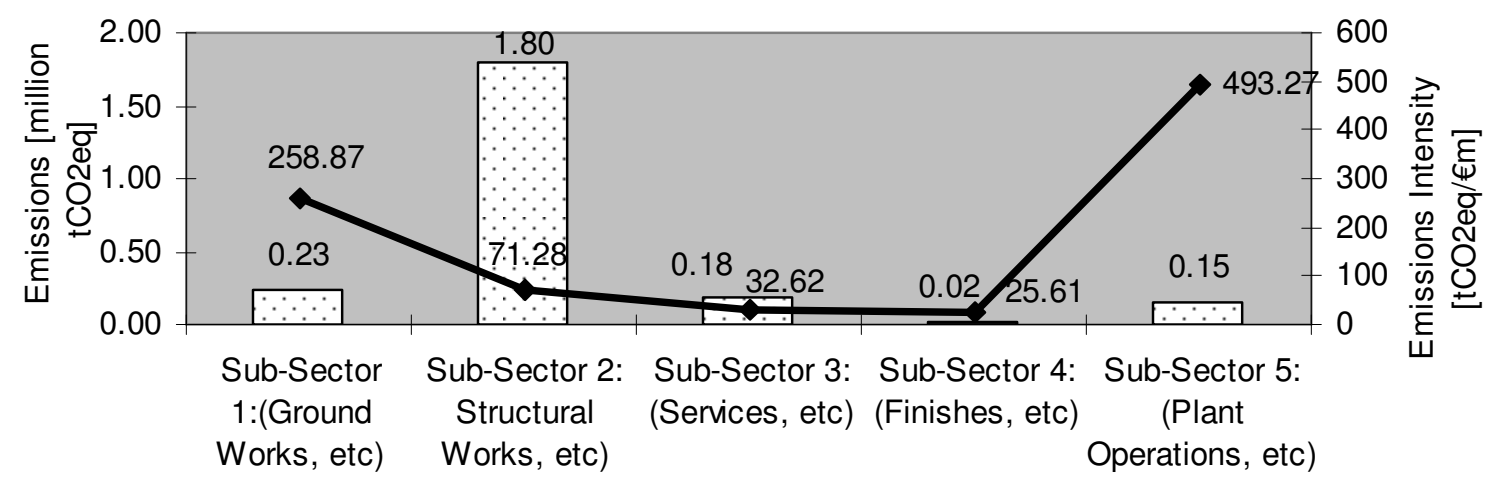

$\multimap$ Sub-Sectoral Direct Emissions [mtCO2eq] œSub-Sectoral Emissions Intensity,idj [tCO2eq/€m] 
Figure 3: Source of I-O Indirect Emissions Intensity in the Construction Sector

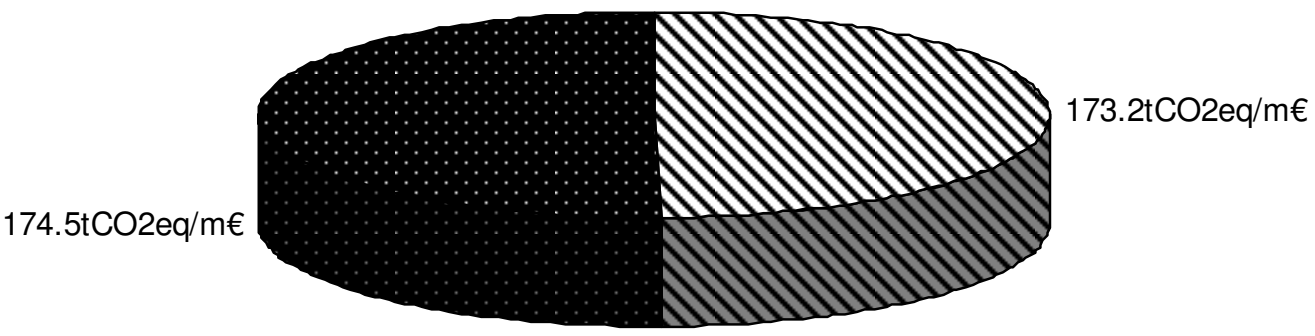

వ Domestic Indirect Emissions a Indirect Emissions in Imported Goods and Services 
Figure 4: Direct sub-sectoral emissions and I-O Indirect emissions arising from domestic and international sources

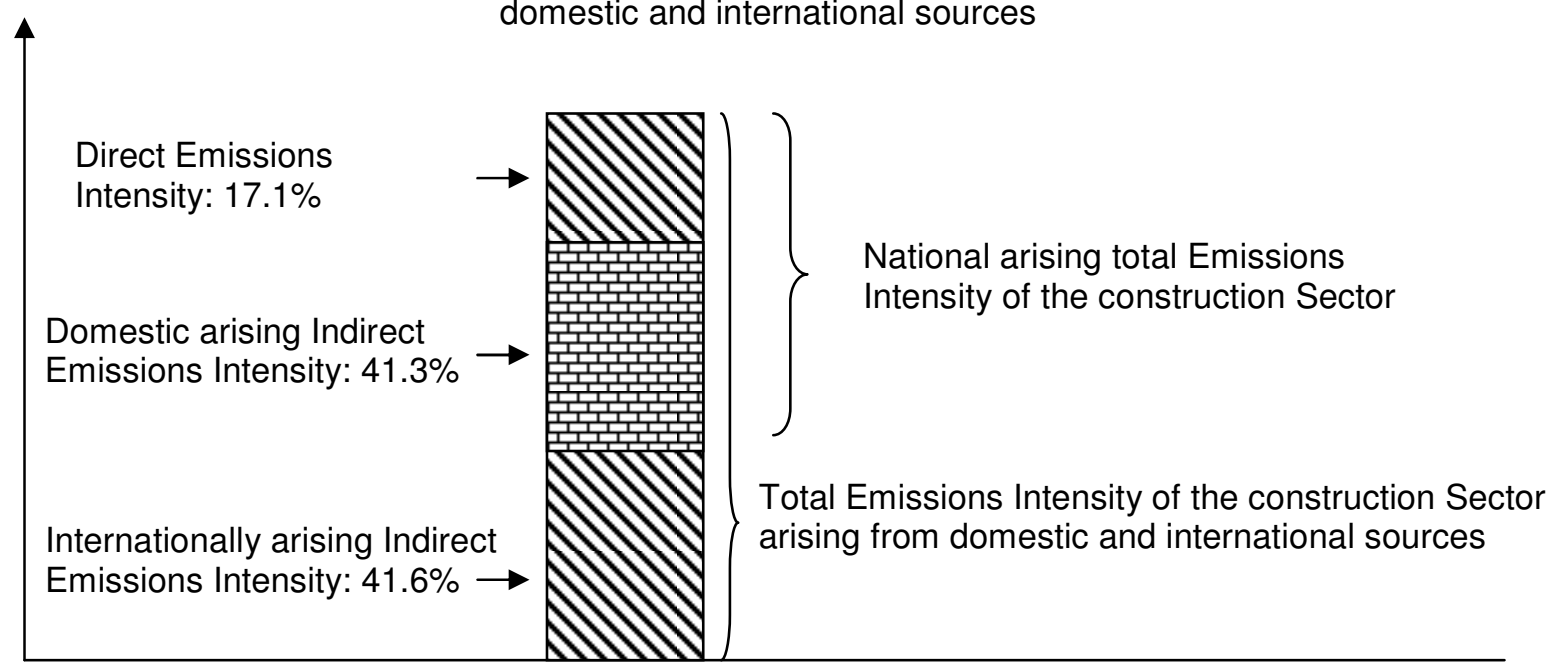


Figure 5: Total Emissions Intensity by Sub-Sector

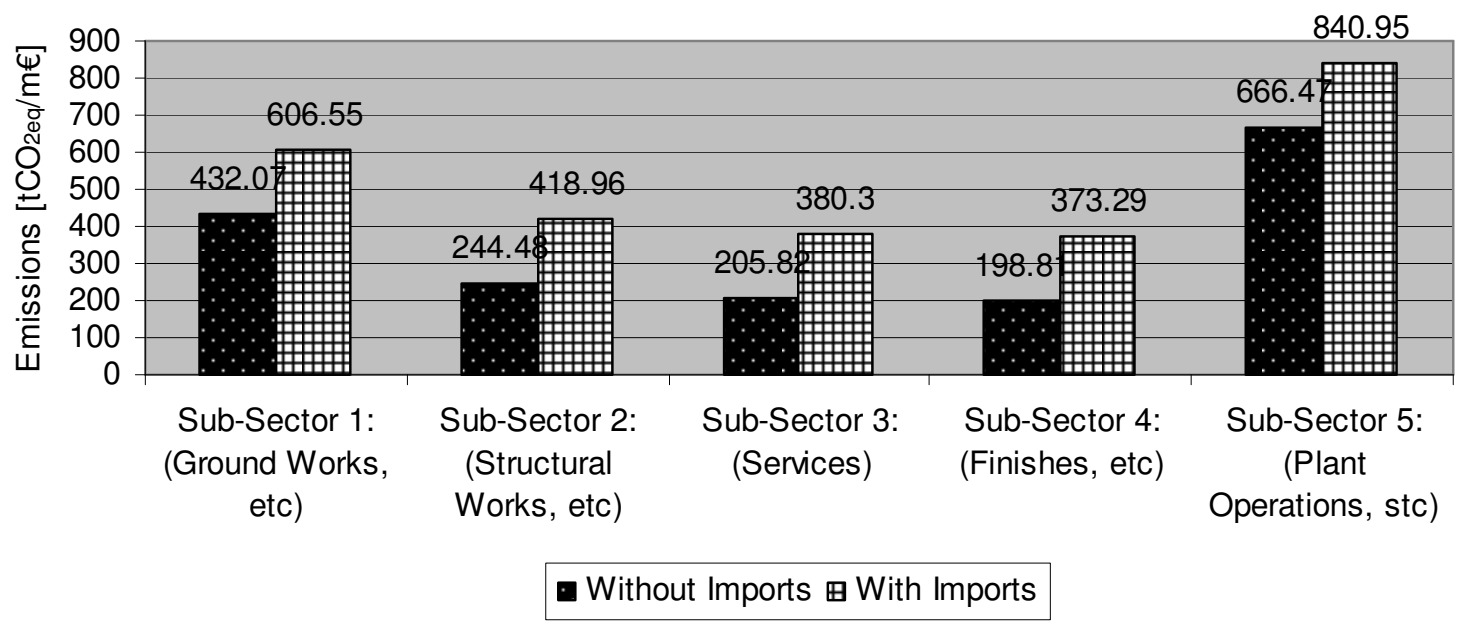


Figure 6: Total Emissions in the Irish Construction Sector

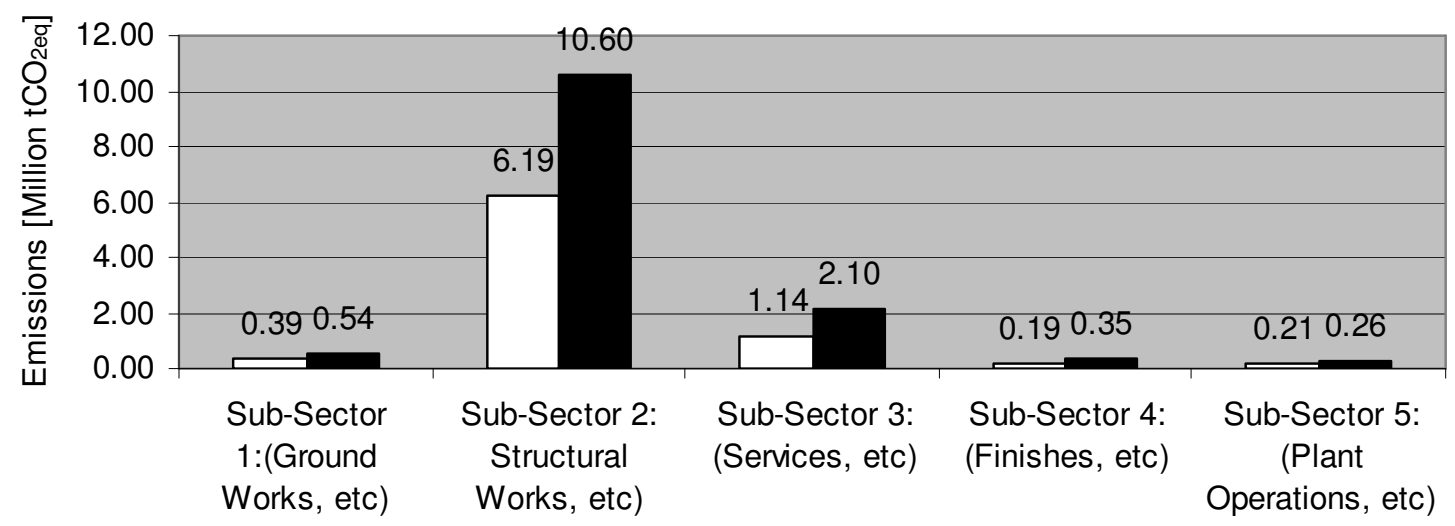

$\square$ Without Imports $\square$ With Imports 


\section{List of Tables}

Table 1: A summary of derived energy data collected for a cross-section construction companies by the Irish Central Statistics Office in their Census of Building and Construction

\begin{tabular}{|c|c|c|c|c|c|c|}
\hline Category & Units & $\begin{array}{l}\text { Ground Works } \\
\text { (NACE 45.1) }\end{array}$ & $\begin{array}{c}\text { Structural } \\
\text { Works } \\
\text { (NACE 45.2) } \\
\end{array}$ & $\begin{array}{c}\text { Services } \\
\text { (NACE 45.3) }\end{array}$ & $\begin{array}{c}\text { Finishes } \\
\text { (NACE 45.4) }\end{array}$ & $\begin{array}{c}\text { Plant } \\
\text { Operation } \\
\text { (NACE 45.5) } \\
\end{array}$ \\
\hline Electricity & GJ & $38,039.1$ & $1,775,133.0$ & $107,466.1$ & $16,441.3$ & $13,825.6$ \\
\hline $\begin{array}{l}\text { Diesel } \\
\text { Output }\end{array}$ & $\begin{array}{l}\text { GJ } \\
€ 000 \mathrm{~s}\end{array}$ & $\begin{array}{l}656,092.3 \\
197,292.0\end{array}$ & $\begin{array}{l}3,739,501.0 \\
5,572,949.0\end{array}$ & $\begin{array}{c}436,425.0 \\
1,215,417.0\end{array}$ & $\begin{array}{c}56,933.6 \\
208,831.0\end{array}$ & $\begin{array}{c}447,996.9 \\
69,054.0\end{array}$ \\
\hline
\end{tabular}

Source: Central Statistics Office, CSO (2007) 
Table 2: Electricity and Diesel emission factors in tonnes/GJ taking account of generating efficiencies

\begin{tabular}{rccccc}
\hline \multicolumn{1}{c}{ Fuel } & $\begin{array}{c}\text { Gen. } \\
\text { Eff.( } \eta)\end{array}$ & $\begin{array}{c}\text { Fuel Mix } \\
\text { Ratio }\end{array}$ & $\begin{array}{c}\mathrm{CO}_{2}[\mathrm{t} / \mathrm{GJ}] \\
\times 10^{-6}\end{array}$ & $\begin{array}{c}\mathrm{N}_{2} \mathrm{O}[\mathrm{t} / \mathrm{GJ}] \\
\times 10^{-6}\end{array}$ & $\begin{array}{c}\mathrm{CH}_{4}[\mathrm{t} / \mathrm{GJ}] \\
\times 10^{-6}\end{array}$ \\
\hline Electricity: & & & & & \\
Coal & 0.370 & 0.25 & 88418.60 & 2.11 & 1.50 \\
Oil & 0.380 & 0.13 & 78500.00 & 2.00 & 3.00 \\
Peat & 0.385 & 0.09 & 105949.30 & 1.83 & 1.56 \\
Natural Gas & 0.414 & 0.46 & 55196.40 & 0.69 & 2.50 \\
Renewable & 1.000 & 0.07 & 0.00 & 0.00 & 0.00 \\
Diesel & - & - & 73300.00 & 1.77 & 3.95
\end{tabular}

Source: Sustainable Energy Ireland (2007) and National Lab for Sustainable Energy (2007) 
Table 3: Primary Energy Factors, Average energy Tariffs and Emission Factors for Ireland. Source (Sustainable Energy Ireland, 2006 and IEA, 1998)

\begin{tabular}{ccc}
\hline Energy Supply Sector & $\begin{array}{c}\text { Primary Energy } \\
\text { Factor }\end{array}$ & $\begin{array}{c}\text { Average Energy Tariff } \\
{[\mathrm{GJ} / €]}\end{array}$ \\
\hline Peat & 1.01 & 0.1124 \\
Crude Oil & 1.00 & 0.5055 \\
Coal & 1.00 & 0.3681 \\
Petroleum & 1.01 & 0.1507 \\
Natural Gas & 1.03 & 0.2270 \\
Electricity & 1.11 & 0.0337 \\
Renewable Energy & 1.00 & 0.0686 \\
\hline
\end{tabular}


Table 4: Disaggregation Constant for Ireland. Source: (Wissema, 2006)

\begin{tabular}{cclc}
\hline I-O Sector & Aggregated Energy Supply Sectors & \multicolumn{1}{c}{$\begin{array}{c}\text { Disaggregated Energy } \\
\text { Supply Sectors }\end{array}$} & $\begin{array}{c}\text { Disaggregated } \\
\text { Constants } \\
\mathrm{C}_{\mathrm{d}}\end{array}$ \\
\hline \multirow{3}{*}{$10-14$} & Mining and Quarrying & Peat & 0.136 \\
& & Crude Oil & 0.175 \\
$23 \& 36$ & Coal & 0.116 \\
& Petroleum and 'Other & Petroleum & 0.700 \\
40 & Manufacturing' & Electricity & 0.755 \\
& Electricity and Gas & Natural Gas & 0.205 \\
& & Renewable Energy & 0.040 \\
\hline
\end{tabular}


Table 5: Indirect I-O emissions intensity of Irish construction resulting from each energy supply sector

\begin{tabular}{lccc}
\hline \multicolumn{1}{c}{ Fuel } & $\mathrm{CO}_{2}[\mathrm{t} / \mathrm{m} €]$ & $\mathrm{N}_{2} \mathrm{O}[\mathrm{t} / \mathrm{m€}]$ & $\mathrm{CH}_{4}[\mathrm{t} / \mathrm{m} €]$ \\
\hline Peat & 28.78 & 0.0005 & 0.0004 \\
Crude Oil & 122.22 & 0.0031 & 0.0047 \\
Coal & 66.45 & 0.0016 & 0.0011 \\
Petroleum & 66.07 & 0.0017 & 0.0025 \\
Electricity & 28.13 & 0.0006 & 0.0007 \\
Natural Gas & 33.33 & 0.0004 & 0.0015 \\
Renewable Energy & 0.0000 & 0.0000 & 0.0000 \\
\hline Total Indirect & & & \\
Emissions & 344.99 & 0.0079 & 0.0109 \\
\hline
\end{tabular}

